\title{
Swelling of TMA(tetramethylammonium)- and HDP(hexadecylpyridinium)-Montmorillonites in Water and Toluene Media: Influence of the Type Montmorillonites
}

\author{
C. Volzone*, J.O. Rinaldi, J. Ortiga \\ Centro de Tecnología de Recursos Minerales y Cerámica; CONICET-CIC-UNLP, \\ C.C. 49, Cno. Centenario y 506, (1897) M.B. Gonnet, Prov. Buenos Aires, Argentina
}

Received: June 19, 2000; Revised: October 24, 2000

\begin{abstract}
Organo-clays were prepared by exchange cations of the montmorillonite with tetramethylammonium (TMA)- and hexadecylpyridinium (HDP)-chloride. Two different montmorillonite types were studied. Two amounts of each organic substances ( 1 and 4 cation exchange capacity times of montmorillonite) were contacted with each montmorillonite clay for 1 and $24 \mathrm{~h}$. The solids were characterized by X-ray diffraction and swelling index. The swelling was measured in water and toluene media. The structural characteristics of montmorillonites changed after organo treatment and showed different behaviour in water and toluene media. The type of montmorillonite, the organic cation intercalates (TMA, HDP) and condition of treatment influenced in the different swelling in water and toluene media.
\end{abstract}

Keywords: organo-montmorillonite, tetramethylammonium, hexadecylpyridynium, toluene

\section{Introduction}

Smectites can be converted into organo-smectites and they are effective for adsorption of organic compounds. The hydration interlayer cations of natural bentonites become hydrophilic in water media. Some organic compound such as toluene cannot adsorbed because competes with polar molecules. Nevertheless, if organic cation are intercalated, the bentonite may be hydrophobic and then it could retain toluene molecules. Several papers describe the retention of organic compounds ${ }^{1-10}$. The organo-clays are effective sorbents for remotion organic compounds from water, as rheological additives. The swelling property of the suspension is taken into account in many industrial uses: paints, waxes, cosmetic preparation, lubricants, etc. ${ }^{11,12}$

The aim of this paper is to evaluate the swelling degree in water and toluene media of two different organo-montmorillonites, prepared by intercalation with tetramethylammonium (TMA) and hexadecylpyridinium (HDP).

\section{Materials and Methods}

Two types of montmorillonites (Cheto and Wyoming) were the starting clays and named B1 and B2, respectively.
The montmorillonites were provided by Clay Repository, (SAz-1: Cheto type; Swy-1: Wyoming type).

The cation exchange capacity (CEC) and the structural composition of $\mathrm{B} 1$ and $\mathrm{B} 2$ montmorillonties were presented in previous papers ${ }^{13,14}$. The higher CEC of B1 (110 $\mathrm{meq} / 100 \mathrm{~g})$ than $\mathrm{B} 2(97 \mathrm{meq} / 100 \mathrm{~g})$ is due to high isomorphous substitution in the structure with the $\mathrm{Mg}^{2+}$ replacing $\mathrm{Al}^{3+}$ in the octahedral layer.

Tetramethylammonium (TMA) and hexadecylpyridinium (HDP) were used to prepare organo-montmorillonites. Aqueous solution of TMA chloride or HDP chloride salts was added to the smectite suspension and contacted for 4 and $24 \mathrm{~h}$. The solids were washed to remove excess salts and stored at room temperature. The amounts of organo compounds added to the smectite were 1 and 4 times the cation exchange capacity (CEC) of the smectite. The organo-smectite was named: $\mathrm{B}(\mathrm{A}-\mathrm{C})$ where the $\mathrm{B}$ is bentonite, $\mathrm{B} 1$ or $\mathrm{B} 2$; $\mathrm{A}$ is the amount of organo substances in CEC added, 1 or 4 times; $C$ is the contacted time, 1 or $24 \mathrm{~h}$.

The swelling index (SI) was measured in water and toluene media. Then, 2.00 grams of sample were added to $100 \mathrm{~mL}$ distilled water or toluene and after 24 the volume of sediment was measured. 
The $d(001)$ spacing of sample was measured by means of X-ray diffraction (XRD). A Philips 3020 Goniometer with PW 3710 Controller using $\mathrm{Cu} \mathrm{K} \alpha$ radiation $(\lambda=1.5405 \AA)$ and Ni filter operating at $40 \mathrm{kV}$ and $20 \mathrm{~mA}$ was used.

\section{Results and Discussion}

The hydrophilic and organophilic characteristics of the organo-montmorillonite could be shown by means of the Swelling Index (SI). The SI of both original bentonites, B1 and B2, in water medium (5.3 and $10.0 \mathrm{~mL}$ ) was higher than in toluene medium (3.6 and $3.8 \mathrm{~mL}$ ), Table 1. This behaviour could be related to the hydrophilic behaviour of the natural bentonites because more water was retained between montmorillonite crystals and a small amount of toluene was uptake.

\subsection{Swelling of organo-bentonites in water medium}

The SI of both original bentonites was modified in water medium after organo intercalation, Table 1. The intercalation of TMA in montmorillonites originated a decrease in swelling in water medium. The swelling values of TMA-B1 montmorillonites were smaller $(4.3-4.8 \mathrm{~mL})$ than from TMA-B2 montmorillonites (6.0-7.6 mL), Table 1.

The intercalation of HDP cation in montmorillonites originated higher swelling values in water media for all HDP-B1 (5.5-8.0 mL) than all HDP-B2 (3.7-4.4 mL). The type of montmorillonite and organo substance influenced on SI in water media.

\subsection{Swelling of organo-bentonites in toluene medium}

In toluene medium all SI of HDP-montmorillonites were higher (11.1-32.2 mL) than TMA-montmorillonites (3.6-5.1 mL), Table 1, and the values corresponding to
HDP-B2 montmorillonites were also, higher than in HDPB1 montmorillonites.

The interpretation of this behaviour is not simple, because different factors are present: type of montmorillonite, different amounts of organic molecules added, interaction between toluene and organic molecule and other factors.

\subsection{Comparative swelling between water and toluene media}

In Fig. 1 the swelling index of all samples in water and toluene media is plotted. Three groups can be found: (a) organo-montmorillonites that can swell in water but not in toluene; (b) organo-montmorillonites that can swell in toluene but no in water; and (c) organo-montmorillonites that can swell in water and toluene media. Both type of montmorillonites, B1 and B2, treated with TMA organic substance are included in (a) group; the B2 treated with HDP belongs to (b) group; and the B1 smectites treated with HDP to (c) group (also see Table 1). The different swelling values in water but not in toluene can be modified, for example, by means of intercalation of TMA, whereas the swelling in toluene medium mainly depend on the type of montmorillonites.

High swelling in toluene of B2, $32.3 \mathrm{~mL}$, was obtained with low HDP added with slow contact time, B2(1-4), Figure 1 and Table 1. On the other hand, reverse behaviour (small swelling) was found in B2 montmorilllonite with high amount added and $24 \mathrm{~h}$ contact time, B2(4-24).

\subsection{Interlayer spacing, d(001), in air dried samples}

The $d(001)$ spacing of the montmorillonites increased after HDP treatment evaluated in air dried and at RH of $55 \%$ conditions. The spacing of B1 increased from $14.9 \AA$ to 20.02-26.75 $\AA$; and B2 from $13.00 \AA$ to $18.15-22.58 \AA$ after different conditions of treatment, Table 2.a. Air-dried

Table 1. Swelling Index (SI) of the original montmorillonites and TMA-, HDP-montmorillonites in water and in toluene media

\begin{tabular}{|c|c|c|c|c|c|c|}
\hline \multirow{3}{*}{ Sample } & \multicolumn{6}{|c|}{ Swelling Index (mL) } \\
\hline & \multicolumn{3}{|c|}{ Water } & \multicolumn{3}{|c|}{ Toluene } \\
\hline & Original & TMA & HDP & Original & TMA & HDP \\
\hline B1 & 5.3 & & & 3.6 & & \\
\hline B1(1-4) & & 4.6 & 5.9 & & 4.1 & 13.4 \\
\hline B1(1-24) & & 4.6 & 5.5 & & 3.6 & 15.2 \\
\hline B1(4-4) & & 4.3 & 8.0 & & 4.5 & 12.3 \\
\hline B1(4-24) & & 4.8 & 7.6 & & 5.1 & 12.2 \\
\hline B2 & 10.0 & & & 3.8 & & \\
\hline B2(1-4) & & 7.4 & 3.7 & & 4.4 & 32.3 \\
\hline B2(1-24) & & 7.6 & 4.3 & & 4.0 & 23.3 \\
\hline B2(4-4) & & 6.3 & 4.4 & & 4.7 & 14.6 \\
\hline B2(4-24) & & 6.0 & 4.4 & & 5.0 & 11.1 \\
\hline
\end{tabular}




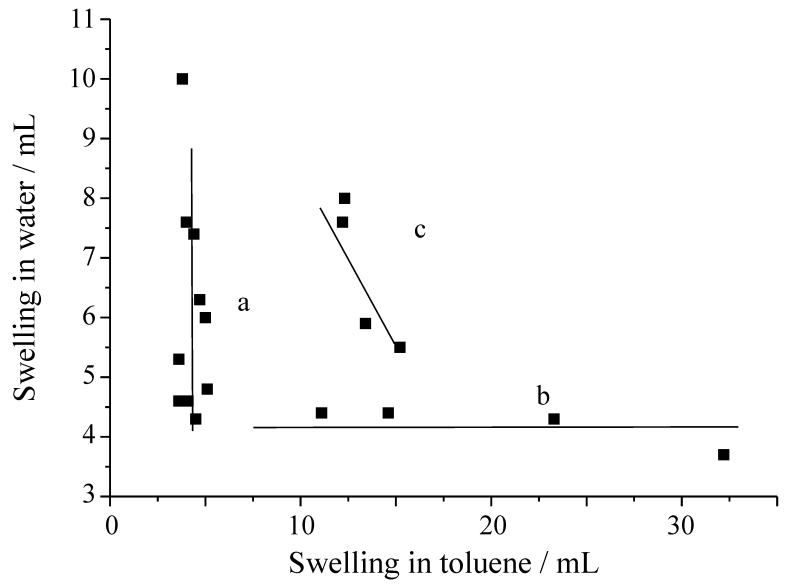

Figure 1. Swelling in water and in toluene media of the original montmorillonites and organo-montmorillonites.

TMA-montmorillonites tended to give $\mathrm{d}(001)$ spacings of 13.71-14.87 $\AA$, similar to that for the air-dried original bentonites (Table 2.a). Lee et $_{\text {al. }}{ }^{15}$ found $13.80 \AA \mathrm{d}(001)$ spacing value in bentonite treated with similar amount of TMA added (3-5 times CEC). Nevertheless, our results as shown in the Table 2.a indicates that the montmorillonites treated with TMA 4 times the CEC showed higher interlayer spacing (13.84-14.87 $\AA$ ). Higher d(001) spacing of montmorillonites was obtained after added TMA 4 times the CEC. The results obtained after contacted time of 4 or $24 \mathrm{~h}$ were similar. The higher d(001) spacings of TMA-B1 than TMA-B2 could be attributed to more retention of TMA in interlayer position due to more CEC of the starting montmorillonite.

\subsection{Interlayer spacing, d(001), of samples after toluene contact}

The $d(001)$ spacing of TMA montmorilllonite after contacting toluene (13.48-14.70 A), Table 2.b, was similar to the one without toluene (13.71-14.87 $\AA$, Table 2.a) and some changes were shown in HDP-montmorillonite (19.5$22.49 \AA$, Table 2.b) regarding the sample without toluene (18.15-26.75 A, Table 2.a).

The interlayer spacing after HDP treatment was higher than after TMA treatment (Table 2). The different spacing values of TMA- and HDP-montmorillonites are attributed to arrangement of organo cations in the interlayer posi$\operatorname{tion}^{16,17}$.

\subsection{Swelling vs. interlayer spacing}

Figure 2 shows the correlation between swelling index and $\mathrm{d}(001)$ spacing of all samples. It is important to mention that the results of $\mathrm{d}(001)$ not necessarily would be proportional to swelling. In swelling test the crystal can uptake all necessarily molecules of the medium. Nevertheless, when the $\mathrm{d}(001)$ was measured in air dried conditions the retained molecules of the medium were limited. It is not easy to
Table 2. Interlayer dimension of the original montmorillonites and TMAand HDP-montmorillonites in: $\mathrm{a}$ ) air dried: $\mathrm{a}$; and b) after toluene contacted and dried: $t$.

a)

\begin{tabular}{lccc}
\hline \multirow{2}{*}{ Sample } & \multicolumn{3}{c}{$\mathrm{d}(001)$ spacing, $\AA$} \\
\cline { 2 - 4 } & Original & TMA & HDP \\
\hline B1a & 14.90 & & \\
B1(1-4)a & & 13.71 & 20.02 \\
B1(1-24)a & 13.82 & 22.11 \\
B1(4-4)a & & 14.87 & 26.75 \\
B1(4-24)a & & 14.74 & 20.37 \\
\hline B2a & \multirow{2}{*}{13.00} & & \\
B2(1-4)a & & 13.95 & 18.15 \\
B2(1-24)a & & 13.89 & 19.28 \\
B2(4-4)a & & 13.84 & 19.32 \\
B2(4-24)a & & 14.13 & 22.58 \\
\hline
\end{tabular}

b)

\begin{tabular}{lccc}
\hline \multirow{2}{*}{ Sample } & \multicolumn{3}{c}{$\mathrm{d}(001)$ spacing, $\AA$} \\
\cline { 2 - 4 } & Original & TMA & HDP \\
\hline B1t & 16.04 & & \\
B1(1-4)t & & 14.70 & 22.49 \\
B1(1-24)t & & 14.70 & 22.26 \\
B1(4-4)t & & 13.77 & 20.24 \\
B1(4-24)t & & 13.72 & 19.95 \\
\hline B2t & \multirow{2}{*}{14.99} & & \\
B2(1-4)t & & 13.48 & 19.50 \\
B2(1-24)t & & 13.71 & 20.00 \\
B2(4-4)t & & 13.90 & 20.39 \\
B2(4-24)t & & 13.49 & 20.32 \\
\hline
\end{tabular}

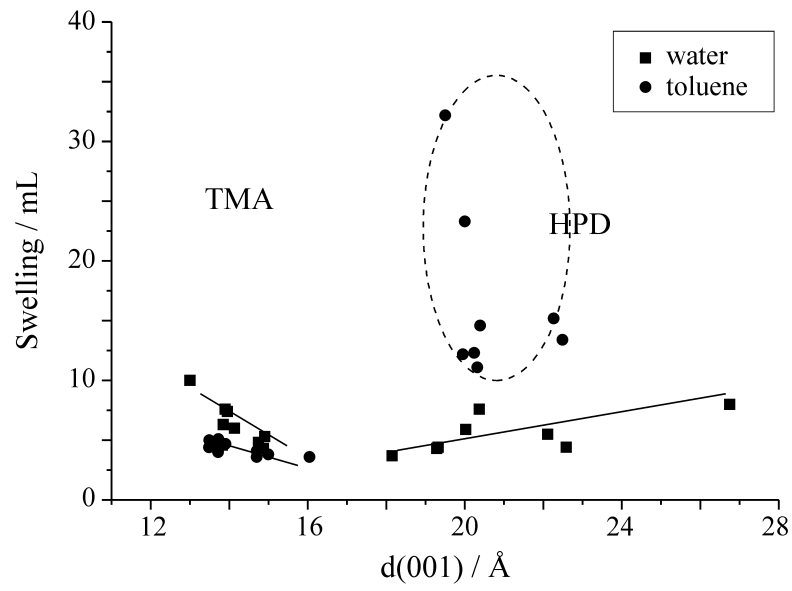

Figure 2. Swelling in water and in toluene media $v s$. interlayer spacing of organo-montmorilllonites. 
explain that fact, nevertheless we found a small correlation between the value of swelling in water and $\mathrm{d}(001)$ spacing of HDP-montmorillonites. The organo-montmorillonite after contacting toluene showed not clear correlation with $\mathrm{d}(001)$ spacing, as shown in the dashed curve in the Fig. 2.

Regarding the correlation between swelling and d(001) spacing of smectites treated with TMA organic, it only can be seen a slight decrease in swelling in both media as $\mathrm{d}(001)$ increased.

Further studies will be necessary to obtain more information about the influence of the characteristics of the original clay on swelling in different media, after organo intercalation.

\section{Conclusions}

Larger swelling of montmorillonites in toluene medium was obtained after intercalation with hexadecylpyridinium cations.

The Wyoming type montmorillonite intercalated with tetramethylammonium or hexadecylpyridinium cations showed higher swelling values in toluene medium than the Cheto-type montmorillonite intercalated with the same organo cations.

It is possible to obtain organo-montmorillonite with selective swelling in water or in toluene according to the organocation intercalated montmorillonite and the type of montmorillonite clay. Nevertheless, more extensive research should be carried out to support the conclusions.

\section{References}

1. Lagaly, G. Characterization of clays by organic compounds, Clay Miner., v. 16, p.1-21, 1981.

2. Lagaly, G. Clay-organic interactions, Phil. Trans. $R$. Soc. Lond. A 311, p. 315-332, 1984.

3. Mortland, M.M.; Shaobai, S.; Boyd, S.A. Clay-organic complexes as adsorbents for phenol and chlorophenols, Clays and Clay Minerals, v. 34, p. 581-586, 1986.

4. Churchman, G.J. Modification of bentonite with different polycations for the uptake of aromatic hydrocarbons from water, International Workshop of Activated Clays, La Plata, Argentina, p. 9, diciembre/1998.

5. Valenzuela-Díaz, F.R.; Abreu, L.D.V. de; Souza-Santos, P. Preparação e propriedades reológicas de argilas esmectíticas organofílicas, Anais do $37^{\circ}$ Congresso Brasileiro de Cerâmica, Curitiba, PR, v. 2, p. 988-995, 1993.

6. Valenzuela-Díaz, F.R.; Abreu, L.D.V. de; Souza-Santos, P. Obtenção de argilas esmectíticas organofílicas partindo-se de argilas de Vitória da Conquista, BA,
Anais do 38 Congresso Brasileiro de Cerâmica, Blumenau, SC, v. 1, p. 354-359, 1994.

7. Valenzuela-Díaz, F.R.; Vieira-Coelho, A.C.; Abreu, L.D.V. de; Souza-Santos, P. Estudos tecnológicos recentes utilizando argilas esmectíticas brasileiras, Anais do 3 Congresso Italo-Brasileiro de Eng. de Minas, Verona, p. 124-130, 1994.

8. Valenzuela-Díaz, F.R.; Amaral, M.S.O. de; SouzaSantos, P. Obtenção de argilas esmectíticas organofílicas a partir de suspensões de bentonita sódica comercial, Anais do 39 Congresso Brasileiro de Cerâmica, Águas de Lindoia, SP, v. 1, p. 231-236, 1995.

9. Valenzuela-Díaz, F.R.; Souza-Santos, P. Obtenção de argilas esmectíticas organofílicas partindo-se de três bentonitas sódicas comerciais, Anais do 39 Congresso Brasileiro de Cerâmica, Águas de Lindoia, SP, v. 1, p. 237-242, 1995.

10. Valenzuela-Díaz, F.R.; Barbosa-Mourão, W.S.; Vieira-Coelho, A.C.; Souza-Santos, P. Obtenção de algumas argilas organofílicas: Influência da concentração das dispersões aquosas de partida, Anais do 12 Congresso Brasileiro de Engenharia Química, CDROM, Porto Alegre, 10 p. Trabalho n. 362, 1998.

11. Jordan, J.W. Organophilic bentonites: I. Swelling in organic liquids, J. Phys. Coll. Chem., v. 53, p. 294302, 1949.

12. Grim, R.E.; Guven, N. Bentonites, geology, mineralogy and uses. New York, Elsevier, 1978.

13. Volzone, C.; Rinaldi, J.O.; Ortiga, O. Adsorption of $\mathrm{N}_{2}$ and $\mathrm{CO}_{2}$ gas by tetramethylammonium-montmorillonites, Anais do 43 Congresso Brasileiro de Cerâmica e $4^{\circ}$ Congresso de Cerâmica do Mercossul, Florianópolis, Santa Catarina, p. 32401, Junho/1999.

14. Volzone, C. OH-Cr(III) in Di- and Trioctahedral Smectites: Texture and Structure Changes, Materials Chemistry and Physics, v. 47, p. 13-16, 1997.

15. Lee, J-F.; Mortland, M.M.; Chiou, C.T.; Kile, D.E.; Boyd, S. Adsorption of benzene, toluene, and xylene by two tetramethylammonium-smectites having different charge densities, Clays \& Clay Miner., v. 38, n. 2, p. 113-120, 1990.

16. Lagaly, G.; Beneke, K.; Weiss, A. Magadiite and $\mathrm{H}$-magadiite: II. H-magadiite and some of its derivatives, Am. Mineral., v. 60, p. 642-650, 1975.

17. Kim, C.S.; Yates, D.M.; Heaney, P.J. The layered sodium silicate magadiite: an analog to smectite for benzene sorption from water, Clays \& Clay Miner., v. 45, p. 881-885, 1997. 